\section{Meadow Creek Stream Restoration ${ }^{1}$ Methodology for Landscape Performance Benefits \\ Case Study Investigation 2014 \\ University of Virginia}

Research Fellow:

Leena Cho

Lecturer in Landscape Architecture

School of Architecture, University of Virginia

\section{Research Assistant:}

Margaret Graham, MLA Candidate

School of Architecture, University of Virginia

\section{Firm Liaison:}

Diane Frisbee, The Nature Conservancy

Dan Frisbee, Water Resource Specialist, Department of Public Works, City of Charlottesville, VA

Meadow Creek is located in Charlottesville, VA (population 43,000). The restoration is about 2 miles from the Downtown Mall and is surrounded by a residential area of single-family homes on wooded lots as well as an apartment complex. The $\$ 3.95$ million project consisted of 7,372 linear feet of stream restoration and 72 acres of conservation easement, completed in March of 2013. The Meadow Creek stream restoration case study project was the result of a close collaboration with both the Nature Conservancy staff and the department of public works for the City of Charlottesville. Their extensive monitoring and reporting process allowed for access to data and resources that would have otherwise been very challenging to collect in the timeframe of our investigation.

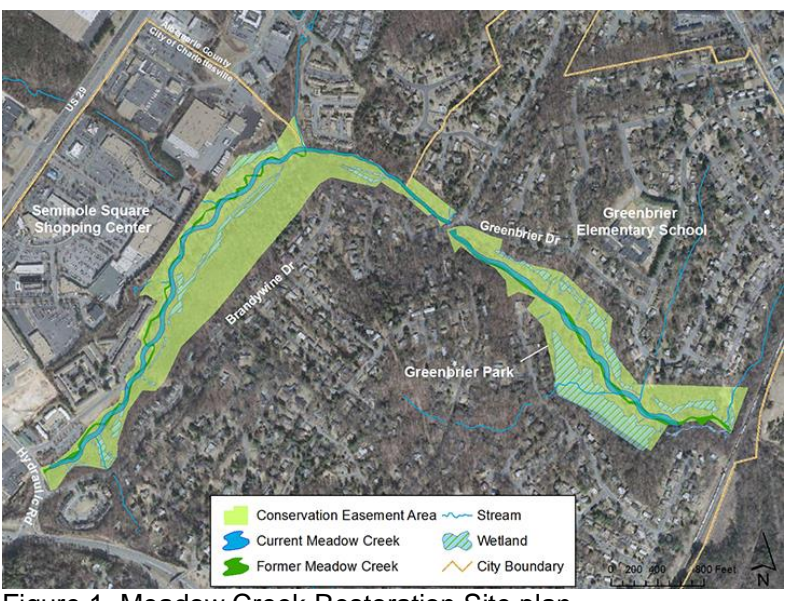

Figure 1. Meadow Creek Restoration Site plan

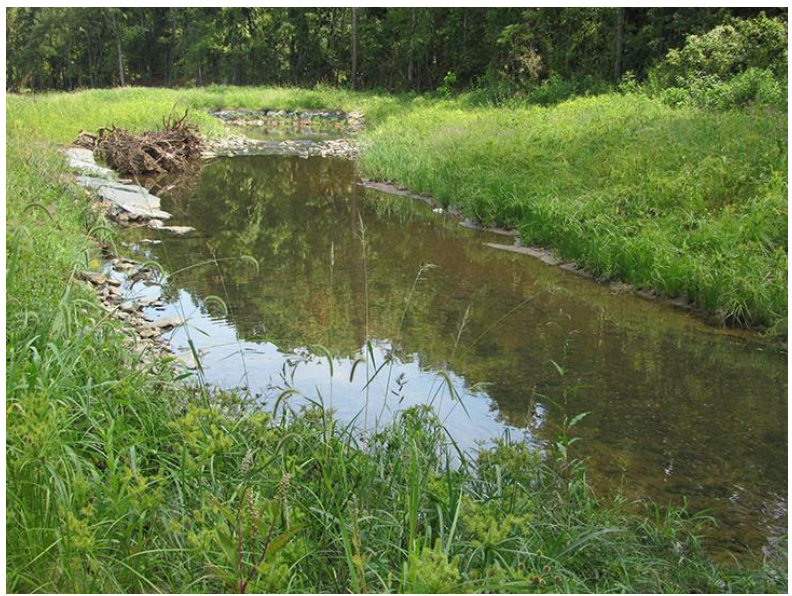

Figure 2. Meadow Creek after the restoration Source: The Nature Conservancy

\footnotetext{
${ }^{1}$ This white paper can be cited as: Cho, Leena, and Margaret Graham. "Meadow Creek Stream Restoration Case Study Methodology." Landscape Architecture Foundation. 2014.
} 


\section{Environmental Performance Benefits}

\section{- Reduces total sediment loading from eroding banks by 1,790 tons per year.}

Method: Bank Erosion Hazard Index

The Bank Erosion Hazard Index (BEHI) is a method for assessing stream bank erosion potential. It assigns point values to several aspects of bank condition and provides an overall score that can be used to inventory stream bank condition over large areas and prioritize restoration efforts.

The BEHI assessment is based on the Rosgen 2001 method to characterize stream bank conditions into numerical indices of bank erosion potential:

http://www.wildlandhydrology.com/assets/Streambank_erosion_paper.pdf

The BEHI methodology evaluates a stream bank's susceptibility to erosion as a function of five factors, including:

1. The ratio of stream bank height to bankfull stage.

2. The ratio of riparian vegetation rooting depth to stream bank height.

3 . The degree of rooting density.

4. Stream bank angle (i.e., slope).

5. Bank surface protection afforded by debris and vegetation.

Each of these five elements is used to compute an erosion risk index, and then the five individual indices are summed to provide a total erosion risk index. The BEHI results can be used not only to evaluate erosion risk potential, but also to estimate total sediment loading from eroding banks by applying indexbased annual bank retreat rates (Rosgen 2001) and a bulk density of bank materials.

Data: Benefit extracted from data provided by VHB Engineers, 2014. Below is one of six stretches of the stream; the figure shows VHB's evaluation of the stream banks according to BEHI ratings.

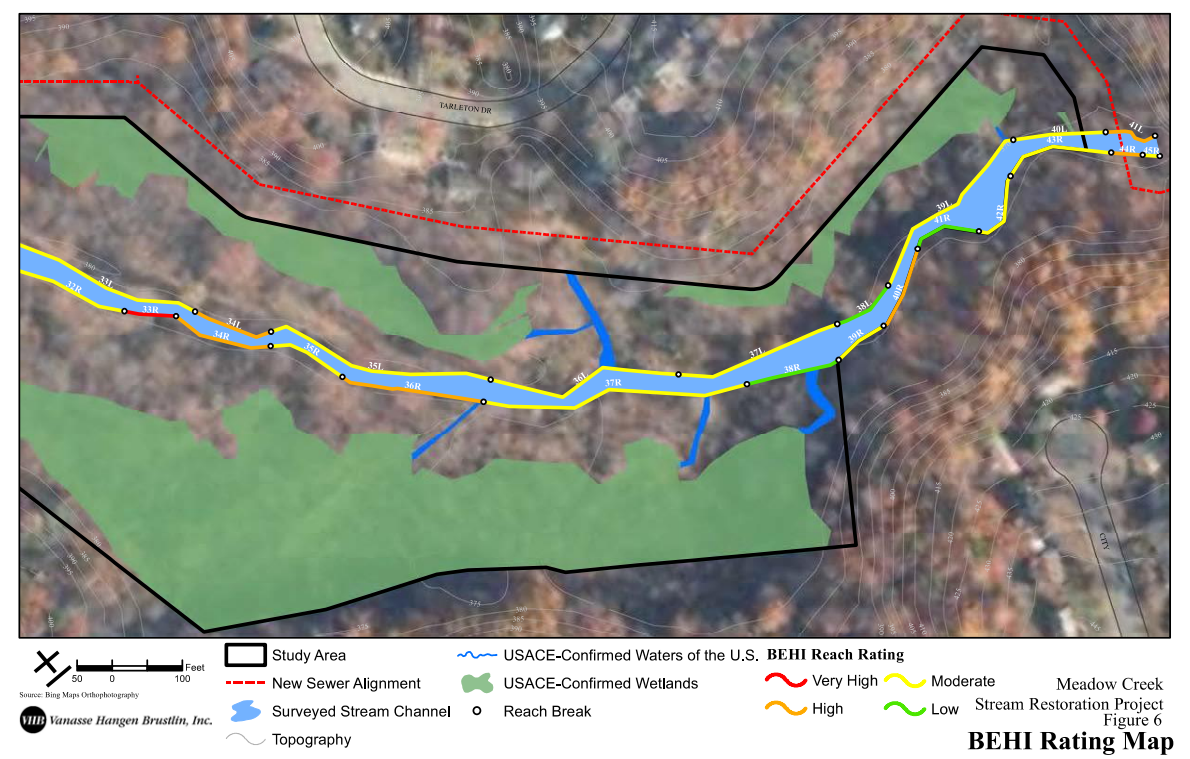

Figure 3. BEHI Reach Rating Map showing the eastern stretch of the stream

Source: VHB

Limitations: This measurement is representative of the stream during the specific monitoring stage, yet sediment measurements may change over time as the stream continues to morph with storm and flooding events. 


\section{References:}

"Bank Erosion Prediction (BEHI, NBS)", United States Environmental Protection Agency http://water.epa.gov/scitech/datait/tools/warsss/pla_box08.cfm (accessed July 8, 2014).

Rosgen, D., "A Practical Method of Computing Streambank Erosion Rate", Proceedings of the Seventh Federal Inteargency Sedimentation Conference, Vol. 2, pp. II-8-15, March 25-29, 2001, Reno, NV http://www.wildlandhydrology.com/assets/Streambank_erosion_paper.pdf

\section{- Estimated to reduce phosphorus by 501 lbs per year, and nitrogen by 553 lbs per year.}

Method: Chesapeake Bay Program interim pollutant reduction accounting method:

The Meadow Creek restoration occurred prior to the Chesapeake Bay Program's issuance of the Recommendations of the Expert Panel to Define Removal Rates for Individual Stream Restoration Projects (January 2014). The Chesapeake Bay Program, therefore, recommends using the revised interim removal rates (below) to estimate the pollutant removal achieved by a stream restoration project.

\begin{tabular}{|l|l|l|l|}
\hline \multicolumn{4}{|l|}{ Revised Interim Removal Rates per Linear Foot of Qualifying Stream Restoration (Ib/ft/yr) } \\
\hline Source & Total Nitrogen & Total Phosphorus & Total Suspended Solids $^{*}$ \\
\hline Revised Interim Rate & 0.075 & 0.068 & $248(43.4)^{*}$ \\
\hline
\end{tabular}

${ }^{*}$ The removal rate for TSS is representative of edge-of-field (EOF) rates and is subject to a sediment delivery ratio (SDR) in the CBWM to determine the edge-of-stream (EOS) removal rate. This sediment delivery ratio is approximately 0.175 and its application to the TSS EOF rate is noted in parentheses. The SDR should be used for planning purposes, however for reporting progress, load reductions using the actual EOF value should be used ( $248 \mathrm{lb} / \mathrm{ft} / \mathrm{yr})$. Scenario Builder will apply a more accurate SDR estimation to the EOF rate.

Data: The Meadow Creek restoration involved 7,372 linear feet of stream channel restoration. As such, the calculations for pollutant removal are as follows:

\begin{tabular}{|l|l|l|l|}
\hline & Restored stream (linear ft) & Interim removal rate (lb/ft/yr) & Pollutant removal (lb) \\
\hline Total Nitrogen & 7,372 & .075 & 553 \\
\hline Total Phosphorus & 7,372 & .068 & 501 \\
\hline Total Suspended Solids & 7,372 & 248 & $1,828,256$ \\
\hline
\end{tabular}

Source: Benefit extracted from data and resources provided by the City of Charlottesville.

Limitations: The limitations of using this methodology for estimating the pollutant removal achieved by the restoration is that, according to the Expert Panel report, "Sediment and nutrient load reductions will always differ, given the inherent differences in stream order, channel geometry, landscape position, sediment dynamics, restoration objectives, design philosophy, and quality of installation among individual stream restoration projects." The interim rates are based on just six studies that performed water quality monitoring of actual stream restoration projects, which is not a robust data set. So the interim rates provide just an estimate for the pollutant removal achieved by the restoration, but at the moment, it is the best estimate available.

\section{References:}

Schueler, Tom, and Bill Stack. "Recommendations of the Expert Panel to Define Removal Rates for Individual Stream Restoration Projects." http://chesapeakestormwater.net/bay-stormwater/baywidestormwater-policy/urban-stormwater-workgroup/urban-stream-restoration/.

Frisbee, Dan. "Meadow Creek Pollutant Removal Methodology." City of Charlottesville, 2014. 
- Increased ecological integrity of the riparian zone, as measured by a $180 \%$ increase in the Plant Stewardship Index, a measure of ecological quality based on the plants found on a site.

Method: The Plant Stewardship Index (PSI) is a tool that calculates the integrity of an ecological system based on its diversity of species and the value of a particular species for its ecological benefits. The Index has catalogued the Coefficient of Conservatism (CC) for thousands of plants based on the following criteria:

0-3 Plants with a high range of ecological tolerances/found in a variety of plant communities

4-6 Plants with an intermediate range of ecological tolerances/associated with a specific plant community

7-8 Plants with a poor range of ecological tolerances/associated with advanced successional state 9-10 Plants with a high degree of fidelity to a narrow range of habitats

Data:

Plant species list extracted from planting plans (VHB engineers, 2014) and The Nature Conservancy's annual report of their 10-year monitoring program. Figure 3, below, details the location of the monitoring sites that examine both the vegetation and the stream profile and structures.

Plant Stewardship Index analysis:

\begin{tabular}{|l|l|}
\hline Pre-restoration & Plants introduced during restoration \\
\hline Total \# of Plant Species: 68 & Total \# of Plant Species: 74 \\
\hline Total \# of Native Plant Species: 36 & Total \# of Native Plant Species: 70 \\
\hline Total Mean CC: 2.05 & Total Mean CC: 4.19 \\
\hline Native Mean CC: 3.53 & Native Mean CC: 4.19 \\
\hline PSI: $\mathbf{1 2 . 2 9}$ & PSI: $\mathbf{3 4 . 5 3}$ \\
\hline
\end{tabular}

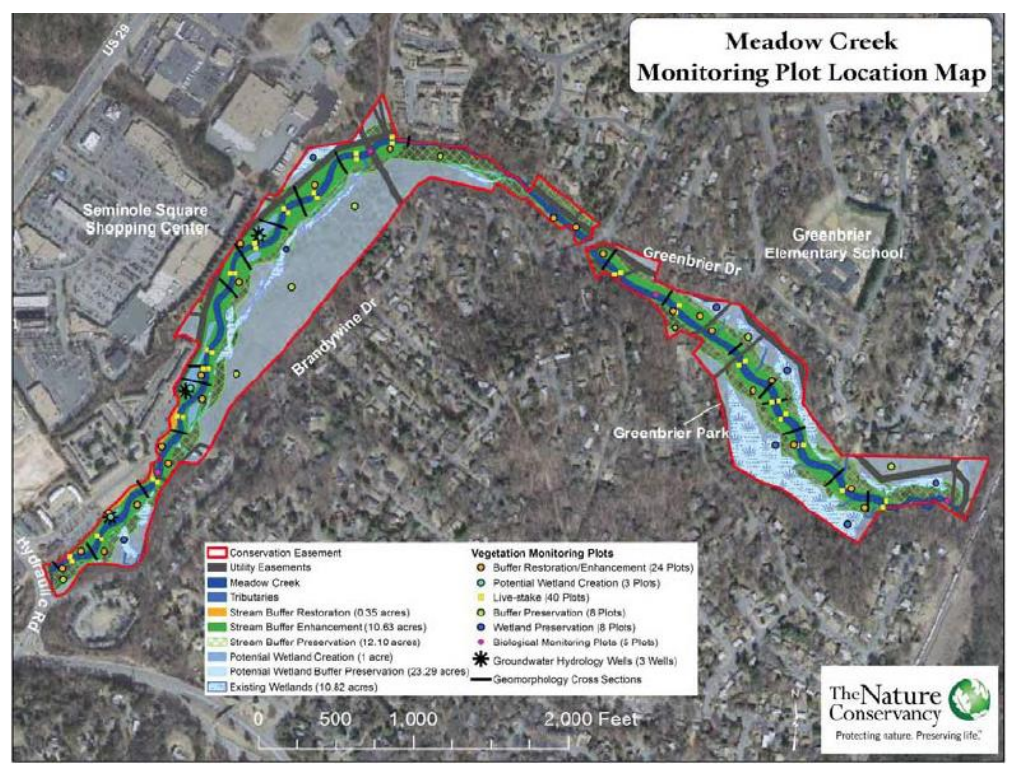

Figure 4. Monitoring locations of wetland, buffer vegetation and live stakes during 2013 reporting at Meadow Creek Source: The Nature Conservancy

Limitations: PSI is designed for use in NJ and PA, yet is of value for Virginia landscapes because its resources are also geared towards the Piedmont region. Additionally, invasive and volunteer species, even with continued maintenance and monitoring, will continue to affect the ecological integrity of the riparian zone. These calculations are a representation of how the ecosystem is affected by the introduction of native species for forest rehabilitation. This is still a young site and this score will change as this dynamic system fluctuates and the plantings mature. 


\section{References:}

"Plant Stewardship Index." Bowman's Hill Wildflower Preserve. http://www.bhwp.org/plant-stewardshipindex.htm (accessed July 3, 2014).

The Nature Conservancy. "Year One Monitoring Report 2013." Virginia Aquatic Resource Trust Fund Project: Meadow Creek: 23-34.

"Invasive Plants Species List." Department of Conservation and Recreation.

http://www.dcr.virginia.gov/natural_heritage/invsppdflist.shtml (accessed July 3, 2014).

\section{Social Performance Benefits}

\section{- Created a positive or very positive change to the stream and parkland for $85 \%$ of 47 Greenbrier neighborhood residents surveyed.}

Method: The research team dispersed the Stream Restoration \& Resident Use survey through the neighborhood email listserv, which provided residents with a link to an online survey via surveyplanet.com. They were given 2 weeks (June 20-July 4) to complete the survey. 47 responses were received and analyzed.

Data: Survey results

$47 \%$ of respondents view the changes to the stream/park as part of the restoration as VERY POSITIVE $38 \%$ of respondents view the changes to the stream/park as part of the restoration as SOMEWHAT POSITIVE

Please rate the status of the park before the Meadow Creek restoration for the following issues:

(0-lowest quality; 5-highest quality)

\begin{tabular}{|l|l|l|l|l|}
\hline & Feature & Rating before & Rating after & Difference \\
\hline Highest & $\begin{array}{l}\text { Proximity to } \\
\text { home/work/school }\end{array}$ & 4.02 & 4.26 & .24 \\
\hline Highest & Location & 3.89 & 4.18 & .29 \\
\hline Most improved & $\begin{array}{l}\text { Overall condition of } \\
\text { park \& facilities }\end{array}$ & 2.72 & 3.60 & .88 \\
\hline Most improved & Park itself & 2.89 & 3.76 & .87 \\
\hline Most improved & Sitting areas & 2.36 & 3.22 & .86 \\
\hline Most improved & Cleanliness & 2.84 & 3.62 & .78 \\
\hline Most improved & $\begin{array}{l}\text { Condition of grass \& } \\
\text { landscapes }\end{array}$ & 2.84 & 3.62 & .78 \\
\hline Improved & Accessibility & 3.04 & 3.76 & .72 \\
\hline Improved & Entrances & 2.73 & 3.41 & .68 \\
\hline Improved & $\begin{array}{l}\text { Condition of paths \& } \\
\text { paved areas }\end{array}$ & 2.85 & 3.51 & .66 \\
\hline
\end{tabular}

Which of the following outcomes of the stream restoration project do you feel is most important?

\begin{tabular}{|l|l|}
\hline $85 \%$ & Permanent protection of 72 acres of parkland \\
\hline $79 \%$ & Improved water quality \\
\hline $74 \%$ & Improved stream habitat \\
\hline $68 \%$ & Removal of invasive vegetation to protect the health \& diversity of the stream-side forest \\
\hline $64 \%$ & Addition of 40 acres of new parkland \\
\hline $55 \%$ & Restored stream resulted in improved visual appeal \\
\hline
\end{tabular}

Limitations: Expanding the data collection beyond an online survey could result in more diversity of responses.

\section{References:}


"Meadow Creek: Stream Restoration \& Resident Use Survey." SurveyPlanet.

https://www.surveyplanet.com (accessed July 8, 2014).

- Increased frequency of visits to Greenbrier Park since before the restoration, a $9 \%$ increase in neighbors who visit the park 2-3 times per week and an $11 \%$ increase in neighbors who visit the park 2-3 times per month, with an average of 68 users on a summer weekend day.

Method: To measure site use, the research team conducted site observations and a neighborhood survey. During the team's site visit to Meadow Creek, a visitor traffic count was conducted (counted all users for 32 -hour periods between $8 \mathrm{am}-8 \mathrm{pm}$, once in the morning, once mid-day and once in the evening) and an activity mapping (types of activities and locations observed by the researchers) following Jan Gehl's PSPL survey method. The observations took place on Saturday June 14, 2014; the weather was mild, a high of $83^{\circ} \mathrm{F}$ and sunny. The research team dispersed the Stream Restoration \& Resident Use survey through the neighborhood email listserv, which provided residents with a link to an online survey (surveyplanet.com). They were given 2 weeks (June 20-July 4) to complete the survey. 47 responses were received and analyzed.

Data:

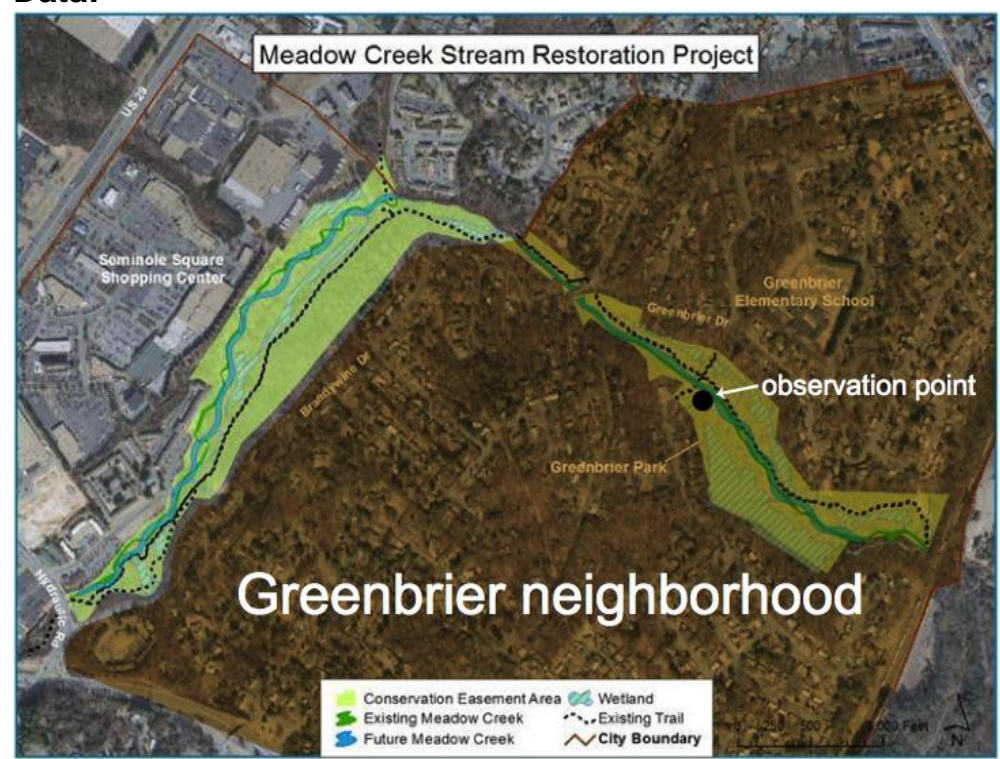

Figure 12. Aerial view of Meadow Creek showing the researcher's observation point at the bridge that connects the Greenbrier neighborhood across Meadow Creek

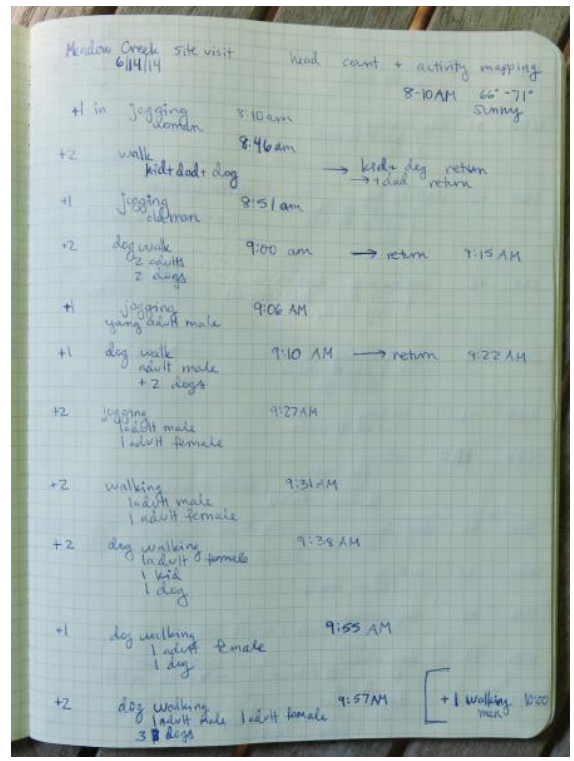

Figure 13. Site observation notes

Survey results:

On average, how often do you use the trails and green space by the stream?

Before: $\quad 17 \%$ everyday $23 \%$ 2-3 times/week $19 \%$ 2-3 times/month

After: $\quad 13 \%$ everyday

$32 \%$ 2-3 times/week

30\% 2-3 times/month 
Limitations: The limited research timeframe and summertime climate impacted the results of our traffic count and activity mapping in a way that may have affected our overall numbers. Furthermore, the survey asks respondents to recall how they used the park prior to the restoration, and therefore does not represent true before and after results.

\section{References:}

"Meadow Creek: Stream Restoration \& Resident Use Survey." SurveyPlanet.

https://www.surveyplanet.com (accessed July 8, 2014).

\section{- Engaged 638 people in research, tours, monitoring, and maintenance activities since the inception of the stream restoration.}

Method: Dan Frisbee and Diane Frisbee have recorded all events associated with stream restoration since the inception of the project. This information is aggregated to summarize the overall involvement of a variety of people with the restored stream.

Data: Below is a record of the total number of people that have been involved with Meadow Creek in a variety of capacities: Research, Education and Volunteer. Two UVA engagements are detailed below the charts.

\begin{tabular}{|c|c|}
\hline Research & \\
\hline Activity & \# people \\
\hline UVA, Dept of Engineering, Master's student research/coursework & 2 \\
\hline $\begin{array}{l}\text { UVA, Dept of Engineering, Professor Culver, undergraduate class research project. This effort conducted } \\
\text { water quality monitoring for sediment, phosphorus, and nitrogen to assess the effectiveness of the restoration. }\end{array}$ & 10 \\
\hline $\begin{array}{l}\text { Piedmont VA Community College, horticulture class project - looked at soils, landscape, etc. to come up with } \\
\text { mock planting plan for project and compared to what was actually planted }\end{array}$ & 6 \\
\hline VA Tech, planning student project, looking at plantings and water quality benefits & 2 \\
\hline $\begin{array}{l}\text { Tandem Friends School - collected water quality data, looked at surrounding land use and watershed } \\
\text { condition and compared to water quality measurements they were taking }\end{array}$ & 6 \\
\hline $\begin{array}{l}\text { UVA, Landscape Architecture graduate student project - Tim Beatley's student did a video of the project, with } \\
\text { interviews of a number of people }\end{array}$ & 2 \\
\hline TOTAL & 28 \\
\hline
\end{tabular}

Education - Tours/Presentations/Events

\begin{tabular}{|l|r|}
\hline Activity & \# people \\
\hline $\begin{array}{l}\text { Tour - TNC CPCG - a group of TNC donors/prospects that represent young professionals in the } \\
\text { Charlottesville area }\end{array}$ & 6 \\
\hline Tour - Biophilic Cities Workshop for UVA Landscape Architecture Dept - internationally attended & 20 \\
\hline $\begin{array}{l}\text { Event - World Water Monitoring Day 2008 - several educational stations were set up, such as biological } \\
\text { stream monitoring, for local children to participate in }\end{array}$ & 20 \\
\hline Presentation - Rivanna Conservation Society Brown Bag 2013 - local audience & 10 \\
\hline Presentation - Tamarisk Coalition Webinar - national audience & 10 \\
\hline Presentation - Middle James Roundtable - Virginia audience & 40 \\
\hline Presentation/tour - TNC staff brown bag - local audience & 20 \\
\hline Event - Ribbon cutting upon project completion - local/state audience & 20 \\
\hline Tour - Rivanna Regional Stormwater Education Partnership - local audience & 8 \\
\hline Tour - Rivanna River Basin Commission - local audience & 10 \\
\hline Tour - Tim Beatley's landscape architecture class & 15 \\
\hline Tour - Leena Cho's landscape architecture class & 14 \\
\hline Tour - Charlottesville City staff tour & 8 \\
\hline Events - 3 public meetings - local audience & 150 \\
\hline Tour - Charlottesville Area Tree Stewards (April 2014) - local audience & 15 \\
\hline Four public meetings for the Meadow Creek Valley Master Plan development (this is the name of the new & 140 \\
\hline
\end{tabular}


park associated with the restoration area) - local audience

Volunteer Engagement

\begin{tabular}{|l|r|}
\hline Activity & \# people \\
\hline Benthic macroinvertebrate monitoring (3x/yr for 6 yrs, 2 volunteers) & 37 \\
\hline Clean the Bay Day 2013 - trash removal work day & 2 \\
\hline Invasive species removal work days (Luke Dupont) & 10 \\
\hline Other stream cleanups (3 events) & 38 \\
\hline $\begin{array}{l}\text { Janna Vetrova - volunteer landscape architect who did a rendering of the future restored Meadow Creek } \\
\text { which was used on signs in the project area }\end{array}$ & 1 \\
\hline Master Naturalist Tree Planting work day & 7 \\
\hline Clean the Bay Day 2014 - trash removal work day & 9 \\
\hline & \\
\hline TOTAL & 104 \\
\hline
\end{tabular}

1. University of Virginia School of Engineering: Water-quality monitoring following completion of Charlottesville's Meadow Creek Restoration Project. The Meadow Creek restoration, run by the City of Charlottesville in conjunction with The Nature Conservancy, is one of the longer urban stream restorations in the country, Culver said. "They were doing some follow-up monitoring. Water-quality monitoring was one thing they were not doing, but were interested in, so that's what my students chose to work on." Her students programmed and deployed robotic samplers to collect water samples during several storm events, then analyzed those samples back at the lab. They also used a computer model to simulate the movement of nutrients and sediments through the system under different conditions. 1 faculty, 5 undergraduate students.

Publicity: http://ce.virginia.edu/pubs/newcourse.html

2. University of Virginia School of Architecture, Department of Landscape Architecture: Officially adopted portion of the restored Meadow Creek in 2013 through the Charlottesville Parks and Recreation Department, and has been participating in volunteer stream clean up twice a year with average facultystudent team of 12 .

Publicity: http://www.arch.virginia.edu/resources/lar-students-adopt-and-clean-section-meadow-creek

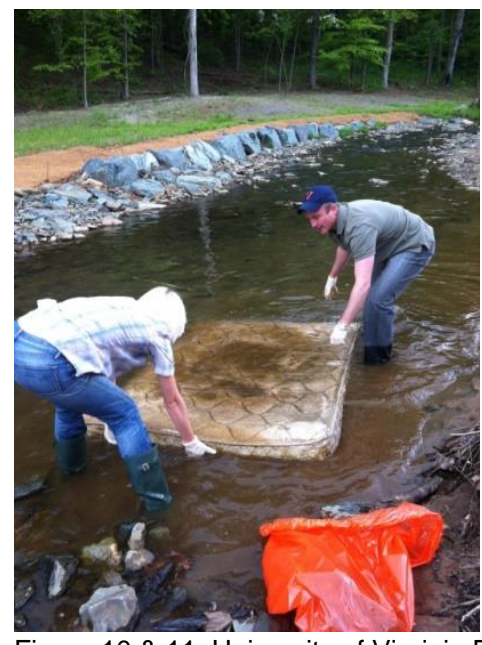

Figure $10 \& 11$. University of Virginia litter twice during the school year.

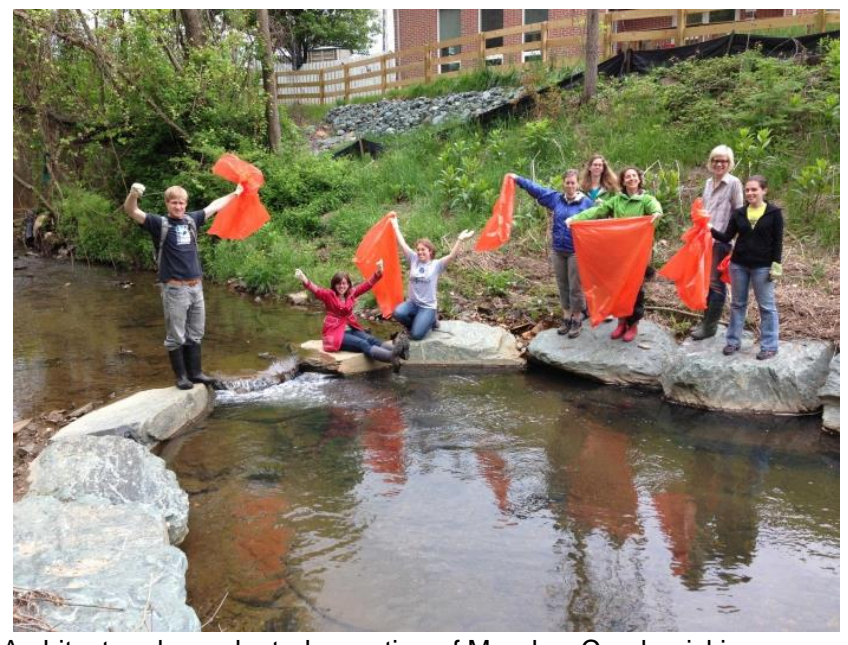

adopted a section of Meadow Creek, picking up Source: UVA Landscape Architecture Department

Limitations: This data is cumulative and therefore will grow in the years to come. It is accurate as of July 10, 2014.

\section{References:}

Diane Frisbee, email message with the author, July 8, 2014. 
- Provides 40 acres of new public parkland adjacent to 223 units of public and lowincome housing.

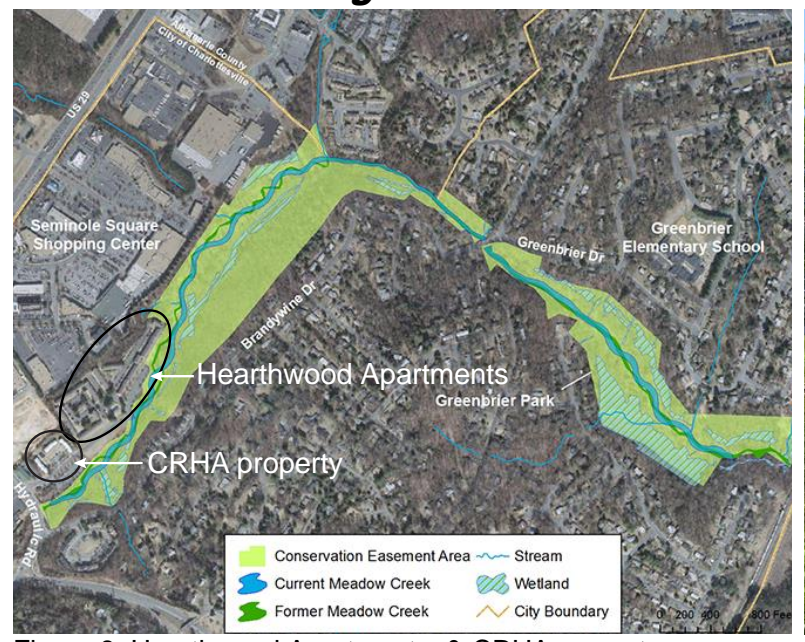

Figure 8. Hearthwood Apartments \& CRHA property adjacent to west side of Meadow Creek restoration

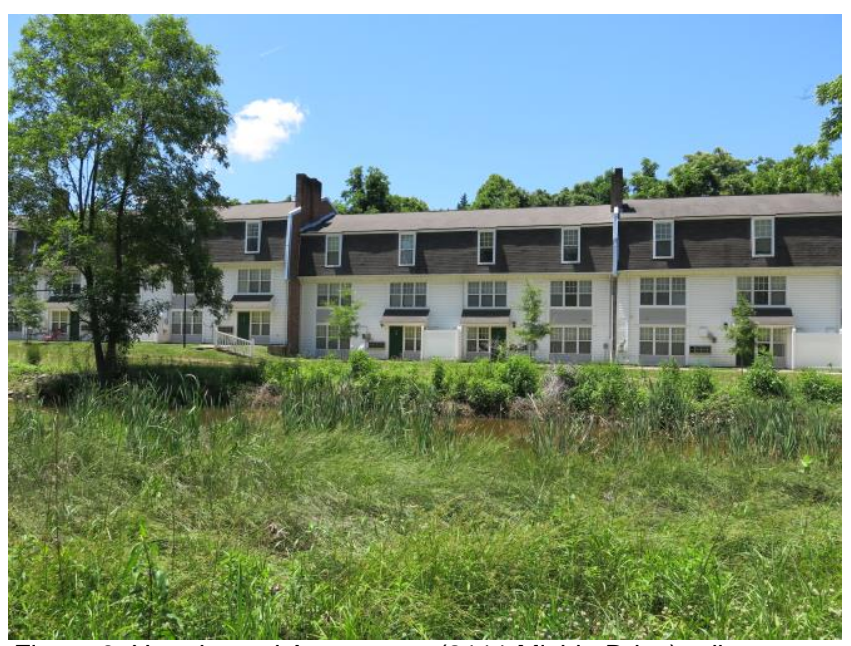

Figure 9. Hearthwood Apartments (2111 Michie Drive) adjacent to a new wetland

Method: The research team collected Information about residences adjacent to the project site from maps, online resources and communication with Dan Frisbee of the City of Charlottesville.

Data: Hearthwood Apartment is a low-income housing property, involved in the Section 8 Housing Choice Voucher program. It serves as a placement for recent Afghan refugees to Charlottesville and contains 200 units (41 studio apartments, 39 1-bedroom apartments, 100 2-bedroom apartments, and 20 3 -bedroom apartments). Also on Michie Drive is a 23 unit public housing site (12 2-bedrooms, and 113 bedrooms) managed by the Charlottesville Redevelopment and Housing Authority (CRHA).

Limitations: After repeated calls to the property owner at Hearthwood, we were unable to get permission to survey the residents to best understand the impact of the project on their use of the space and their perceptions of the stream restoration.

\section{References:}

City of Charlottesville. "Charlottesville Redevelopment and Housing Authority (CRHA)." http://www.charlottesville.org/lndex.aspx?page=28.

Find The Best. "Low Income Housing: Hearthwood Apartments." http://low-incomehousing.findthebest.com///28633/Hearthwood-Apartments.

Method: Using land acquisition data from the Nature Conservancy and City of Charlottesville, the acreage of the new parkland was compared to the acreage of the existing Greenbrier Park. Both new and existing parkland are now under a conservation easement to prevent future development and preserve the ecological integrity of the riparian zone. Additionally, this new public green space now provides the residents of the Hearthwood Apartments with passive recreation space along the creek corridor. 
Data:

\begin{tabular}{|l|l|l|}
\hline Existing & New & Total \\
\hline 32 acres & 40 acres & 72 acres \\
\hline & & $125 \%$ increase \\
\hline
\end{tabular}

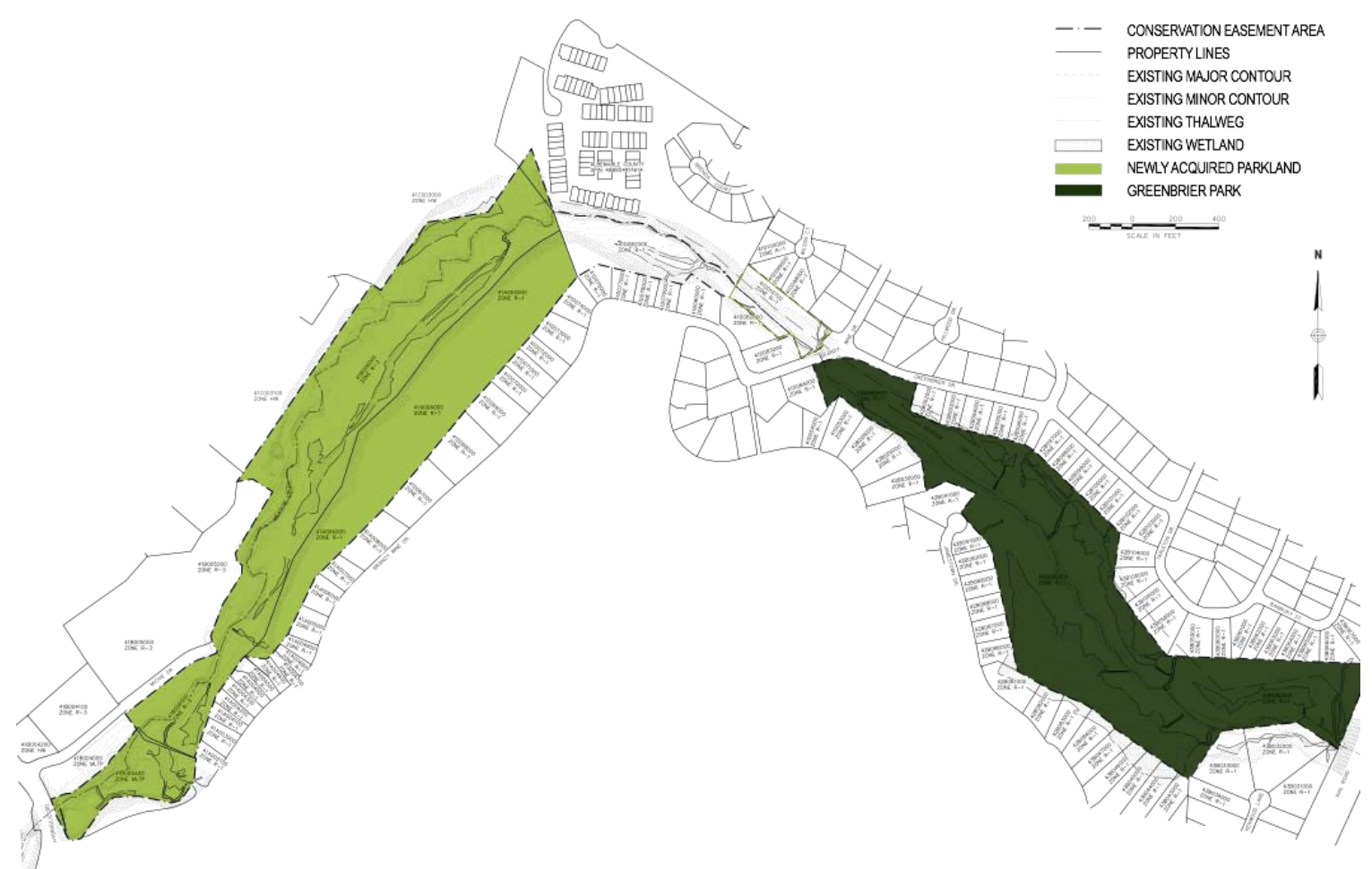

Figure 6. Expansion of parkland along the Meadow Creek restoration

Limitations: These two sets of parkland have different characteristics, making it challenging to have a direct comparison. They both contain sections of the Rivanna Trail, yet Greenbrier park is a passive recreation area with dirt paths along the stream and some seating in the form of picnic tables and benches whereas a section of the added parkland along Michie Drive has been programmed for an open play field and playground that has yet to be implemented.

\section{References:}

Frisbee, Dan. "Meadow Creek Restoration." Lecture, Presentation to Landscape Architecture Waterworks class from City of Charlottesville, Charlottesville, March 21, 2013.

VHB. "Meadow Creek Final Plan Set." April 18, 2012. 


\section{Economic Performance Benefits}

\section{- Catalyzed additional improvement, including a \$300,000 multi-use commuter trail and connector bridges that will further enhance the project site.}

Method: Benefit extracted from observing the Meadow Creek Stream Valley Master Plan 2013 and communicating with Dan Frisbee of the City of Charlottesville.

Data: According to the June 3, 2013 City of Charlottesville City Council Agenda regarding the Meadow Creek Stream Valley Master Plan Adoption, the completion of the stream restoration contributed to moving forward with developing this master plan. It states, "The City has worked to acquire approximately 40 acres of new parkland between the existing Meadow Creek Gardens and Greenbrier Park along Meadow Creek. During the past four (4) years, sewer and stream restoration projects have altered the landscape, creating opportunities for new trails, improved forest and stream management, and recreational opportunities." Furthermore, according to Dan Frisbee of the City of Charlottesville, "The notion of and desire for a commuter trail already existing, but the creation of the new parkland that was driven by the restoration allowed and accelerated the process for getting it funded and ultimately built (in the next couple years)."

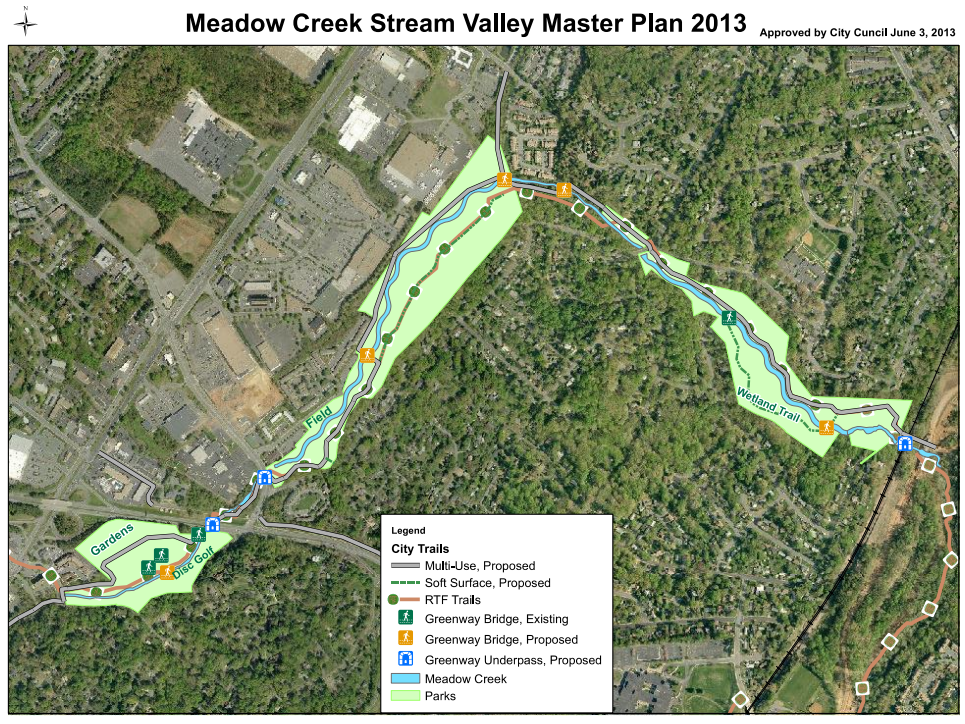

Figure 7. Meadow Creek Stream Valley Master Plan, 2013

Source: City of Charlottesville

Limitations: As this is a Master Plan, the city has only budgeted for particular features and has set aside an amount for the next 2 years. The features are likely to take longer than two years to complete and will require more financing.

\section{References:}

City of Charlottesville. "Charlottesville: Meadowcreek Stream Valley."

http://www.charlottesville.org/Index.aspx?page=378 (accessed July 23, 2014).

Daly, Brian. "City Council Agenda."

http://charlottesville.granicus.com/DocumentViewer.php?file=charlottesville_1df5dff93a71613e5e3f82ee 252d7770.pdf (accessed July 23, 2014). 
Dan Frisbee, email message to the author, June 25, 2014.

\section{Cost Comparison:}

- The Rivanna Water \& Sewer Authority has and will continue to save money on emergency repairs for the major sanitary sewer line adjacent to the stream, which, due to streambank erosion and migration, was located within the stream in some locations. In the last 10 years, 4 major emergency repairs occurred, costing $\$ 284,984$.

Method: Rivanna Water and Sewer Authority (RWSA) and The Nature Conservancy provided details of the emergency repairs and the relationship between the sewer and the stream restoration project. Many of these repairs were done as a result of stream erosion as well as structural deterioration of the sewer since it was built in the 1950s and was undersized for current wet weather flows.

Data: Emergency Repair Costs

\begin{tabular}{|l|l|l|}
\hline Location & Year & Cost \\
\hline Branbury Repair Phase 1 & 2006 & $\$ 92,902$ \\
\hline Branbury Repair Phase 2 & 2007 & $\$ 55,075$ \\
\hline Hearthwood Apartments & 2009 & $\$ 115,738$ \\
\hline Michie Drive & 2010 & $\$ 21,269$ \\
\hline Total Repair Costs & & $\$ 284,984$ \\
\hline
\end{tabular}

Limitations: Stream erosion was not the only cause of sewer deterioration. Prior to the installation of the new sewer interceptor, the pipes were 50 years old and had reached the end of their useful life. Many of the emergency repairs conducted were a result of the sudden failure of this aging infrastructure. Therefore, it is difficult to attribute all of the repairs costs to stream erosion. However, the collaboration of the Rivanna Water and Sewer Authority and the Nature Conservancy to create paths for the stream and new sewer that do not conflict will prevent further emergency repairs.

\section{References:}

"Rivanna Water and Sewer Authority - Meadow Creek Interceptor Upgrade." Rivanna Water and Sewer Authority. http://www.rivanna.org/meadowcreek/index.htm.

- The City of Charlottesville purchased 7.8 acres, whereas landowners donated 31 acres. Only $20 \%$ of the total value of the new parkland was spent to acquire the land for the project, saving approximately \$276,000.

Method: To create the conservation easement around the Upper Reach of the project, 40 acres were acquired from 4 different landowners. Two of the properties were donated while 2 others were purchased by the City of Charlottesville with some help from The Nature Conservancy. The project cost was greatly reduced by the donation of 31 acres. Here, we are comparing the cost of purchasing all 40 acres versus the actual amount that was spent on land acquisition.

Data:

landowner method size

HAAS Associates

DONATED

13 acres estimated value

JAZAN

DONATED

18 acres

$\$ 115,833.38$

$\$ 160,384.68$ 
REGION 10

CANON
PURCHASED $\$ 20,000 \quad 3.3$ acres

PURCHASED $\$ 49,500 \underline{4.5 \text { acres }}$

38.8 acres
$\$ 20,000$

$\$ 49,500$

$\$ 345,718.06$

If 3.3 acres is valued at $\$ 20,000$, and 4.5 acres is valued at $\$ 49,500$, then 1 acre is estimated at $\$ 8,910.26$

Only $20 \%$ of the actual total value of the new parkland was spent to acquire land for the stream restoration. Land estimated at $\$ 276,218.06$ was donated, and therefore the project team could spend more funds on structures and vegetation to benefit the stream restoration.

Limitations: This calculation assumes that the amount the City paid for the 2 purchased parcels is equal to the value of the land adjacent to it that amounted to the continuous 40 acres of new parkland.

\section{References:}

Dan Frisbee, email message to the author, June 13, 2014.

\section{Combined References:}

"Bank Erosion Prediction (BEHI, NBS)", United States Environmental Protection Agency http://water.epa.gov/scitech/datait/tools/warsss/pla_box08.cfm (accessed July 8, 2014).

"City Assessor Online Records/GIS." City of Charlottesville Department of City Assessor." (accessed July 3, 2014).

City of Charlottesville. "Charlottesville: Meadowcreek Stream Valley."

http://www.charlottesville.org/Index.aspx?page=378 (accessed July 23, 2014).

City of Charlottesville. "Charlottesville Redevelopment and Housing Authority (CRHA)."

http://www.charlottesville.org/Index.aspx?page=28

Daly, Brian. "City Council Agenda."

http://charlottesville.granicus.com/DocumentViewer.php?file=charlottesville_1df5dff93a71613e5e3f82ee

252d7770.pdf (accessed July 23, 2014).

Dan Frisbee, email message to the author, June 13, 2014.

Dan Frisbee, email message to the author, June 25, 2014.

Dan Frisbee, email message with the author, July 9, 2014.

Diane Frisbee, email message with the author, July 8, 2014.

Find The Best. "Low Income Housing: Hearthwood Apartments." http://low-incomehousing.findthebest.com///28633/Hearthwood-Apartments.

Frisbee, Dan. "Meadow Creek Pollutant Removal Methodology." City of Charlottesville, 2014.

Frisbee, Dan. "Meadow Creek Restoration." Lecture, Presentation to Landscape Architecture Waterworks class from City of Charlottesville, Charlottesville, March 21, 2013.

"Invasive Plants Species List." Department of Conservation and Recreation.

http://www.dcr.virginia.gov/natural_heritage/invsppdflist.shtml (accessed July 3, 2014). 
"Meadow Creek: Stream Restoration \& Resident Use Survey." SurveyPlanet.

https://www.surveyplanet.com (accessed July 8, 2014).

Micah Hedgepeth, City of Charlottesville Assessor, email message to the author, June 16, 2014.

"Plant Stewardship Index." Bowman's Hill Wildflower Preserve. http://www.bhwp.org/plant-stewardshipindex.htm (accessed July 3, 2014).

"Rivanna Water and Sewer Authority - Meadow Creek Interceptor Upgrade." Rivanna Water and Sewer Authority. http://www.rivanna.org/meadowcreek/index.htm.

Rosgen, D., "A Practical Method of Computing Streambank Erosion Rate", Proceedings of the Seventh Federal Inteargency Sedimentation Conference, Vol. 2, pp. II-8-15, March 25-29, 2001, Reno, NV http://www.wildlandhydrology.com/assets/Streambank_erosion_paper.pdf

Schueler, Tom, and Bill Stack. "Recommendations of the Expert Panel to Define Removal Rates for Individual Stream Restoration Projects." http://chesapeakestormwater.net/bay-stormwater/baywidestormwater-policy/urban-stormwater-workgroup/urban-stream-restoration/.

The Nature Conservancy. "Year One Monitoring Report 2013." Virginia Aquatic Resource Trust Fund Project: Meadow Creek: 23-34.

VHB. "Meadow Creek Final Plan Set." April 18, 2012. 